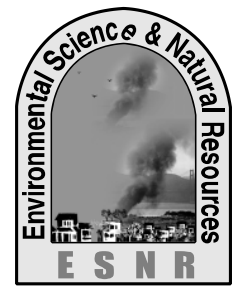

J. Environ. Sci. \& Natural Resources, 7(2): 185-190, 2014

ISSN 1999-7361

\title{
**Compositional Analysis and Development of Jam, Jelly and Squash from Strawberry Cultivated in Bangladesh
}

\author{
M. A. Zubair ${ }^{1}$, M. A. Haque ${ }^{1}$, M. M. Sultana ${ }^{2}$ and S. Akter ${ }^{1 *}$ \\ ${ }^{1}$ Department of Food Technology and Nutritional Science \\ Mawlana Bhashani Science and Technology University, Santosh, Tangail-1902, Bangladesh \\ ${ }^{2}$ Vrije University of Brussels, Brussels, Belgium \\ *Corresponding author: shamoli07@gmail.com
}

\begin{abstract}
The Strawberry was collected from Rajshahi and the pulp was extracted. Then the pulp was analyzed for proximate composition. The proximate analysis of Strawberry pulp showed $91.91 \%$ moisture, $11.5 \%$ TSS, 3.50\% reducing sugar, $2.50 \%$ non-reducing sugar, $6.00 \%$ total sugar, $0.36 \%$ ash, $2.80 \% \mathrm{pH}, 1.12 \%$ acidity and $50.90 \mathrm{mg} / 100 \mathrm{~g}$ vitamin-C. A total three types of products with 3 different formulations were prepared and packed in appropriate containers for storage studies. Products were stored at room temperature and changes during storage were observed at an interval of 30 days for a period of 4 months. A taste panel consisting of 10 panelists studied the acceptability of the samples. The consumers preferences were measured by statistical analysis of the scores obtain from the response of the test panel. Among the products three samples of jam, jelly and squash were awarded the highest scores by the panelists; C2 (Jam: TSS-67\%, Pectin-0.5\%, pH-3.2\%), D2(TSS-67\%, pectin-0.5\%, pH-3.2\%) and E3 (squash: TSS-40\%, Juice 25\%, acidity-1.25\%, KMS-350mg/kg ).
\end{abstract}

Key words: Fruits, Jam, Jelly, Strawberry, Rajshahi

\section{Introduction}

Ready-to-eat fresh fruit has become an important area of potential growth presumably due, in part, to their freshness, low caloric content and commodity to be used an active promotion of fruits and vegetables as basic components of a healthy diet (Corbo et al., 2000). Strawberries are one of the most popular fruits worldwide, rich in nutrients (aminoacids, vitamins and anthocyanins) but also highly perishable, being susceptible to mechanical injury, desiccation, decay and physiological disorders during storage (Martín-Belloso et al., 2006). The shelf life of fresh strawberries stored at low temperatures is usually less than 5 days, and this period is reduced when the product is minimally processed. Improvements in shelf-life can be achieved by using good quality raw products, taking special care during processing and along the trade chain, controlling the storage temperature and using modified atmosphere packaging (Nguyen \& Carlin 1994).

\section{Materials and Methods}

The experiment was done in the laboratory of the Department of Food Technology and Nutritional Science, Mawlana Bhashani Science and Technology University, Tangail and post harvest technology section of Bangladesh agricultural Research Institute (BARI).

\section{Collection of fruits}

The strawberry (Fragaria ananassa) was collected from the Rajshahi and other material collect from the local market of Tangail. The main ingredient for the formulation of the product was sugar, citric acid, pectin, KMS and other chemical used from the laboratory store.

\section{$* *$ Editorial note}

Due to some necessary corrections, this article has been revised in this volume 7(2) and, therefore, has been withdrawn from the previous volume $7(1)$ with the page numbers 271-276.

\section{Determination of Moisture content}

The vacuum oven drying method described by Endel Karmas (1980) was used for determining moisture content where the temperature was maintained at $70^{\circ} \mathrm{C}$ and pressure at about $50-100$ $\mathrm{mg}$ of $\mathrm{Hg}$. In crucible, 10gm sample is taken and placed in an oven at $100^{\circ} \mathrm{C}$ for 6 hours until constant weight attained. Percentage of moisture content was calculated using following equation:

Percentage of moisture $(\%)=\frac{\mathrm{W} 1-\mathrm{W} 2}{\mathrm{~W} 1} \times 100$

Where,

$\mathrm{W}_{1}=$ Initial weight of the sample

$\mathrm{W}_{2}=$ Final weight of the sample

\section{Determination of Ash content}

The inorganic residue remaining after destruction of organic matter is the ash content. The oven-dried sample was taken in muffle furnace at $550^{\circ} \mathrm{C}$ for 4 hours after pre-washing at $200^{\circ} \mathrm{C}$. The difference between oven dried matter and final weight represented the ash which is expressed in percentage. It is calculated by using following formula:

Percentage of $\operatorname{ash}(\%)=\frac{F}{I} \times 100$

Where,

$\mathrm{F}=$ Weight of the sample

I = Initial weight of dry matter

\section{Determination of fat content}

AOAC method (2004) was used to determine crude fat content of the sample.

\section{Determination of $\mathrm{pH}$}

The $\mathrm{pH}$ was first standardized using buffer $\mathrm{pH} 7.00$ for determining the $\mathrm{pH}$ of strawberry and strawberry jam, jelly, squash. Again $\mathrm{pH}$ meter was 
standardized using that buffer and checked the $\mathrm{pH}$ of studied samples.

\section{Determination of acidity}

The acidity was determined by titration using standard sodium hydroxide solution and express as anhydrous citric acid.

$20 \mathrm{~g}$ of sample was taken and placed into the blander machine and homogenized with distilled water. The blended materials were then transferred to a $250 \mathrm{ml}$ volumetric flask and the volume was made to mark with distilled water. $5 \mathrm{ml}$ of solution was taken in a conical flask and titrated with $0.1 \mathrm{~N}$ $\mathrm{NaOH}$ solution just below the end point, using phenolphthalein indicator. The titration was done for several times for accuracy. Present titrable acidity was calculated by using following equation:

Percentage of titrable acidity $(\%)=\frac{\mathrm{T} \times \mathrm{N} \times \mathrm{V} 1 \times \mathrm{E} \times 100}{\mathrm{~V} 2 \times \mathrm{W} \times 1000} \times 100$

Where,

$\mathrm{T}=$ Titre

$\mathrm{N}=$ Normality

$\mathrm{V}_{1}=$ Volume made up

$\mathrm{E}=$ Equivalent weight of acid

$\mathrm{V}_{2}=$ Volume of the sample taken for estimation

$\mathrm{W}=$ Weight of sample

Determination of vitamin $C$ content (ascorbic acid)

Titrametric method: $10 \mathrm{~g}$ sample was taken and it was blended and homogenized with $3 \%$ metaphosphoric acid solution. The homogenized liquid was transferred to a $100 \mathrm{ml}$ volumetric flask and made up with volume of metaphosporic acid solution. Content of flask was then thoroughly mixed and filtered. Then $5 \mathrm{ml}$ of aliquot was taken into a flask and titrated with 2,6-dichlorophenol dye. The dye had been standardized with vitamin $C$ solution to find an equivalent dye factor. The ascorbic acid content of the sample was calculated from the following relationship. Ascorbic acid was determined by the following method. The reagent used for the estimation of vitamin-C is follows:

$\mathrm{Mg}$ of vitamin $-\mathrm{C}$ per $100 \mathrm{~g}$ sample $=\frac{\mathrm{T} \times \mathrm{D} \times \mathrm{V} 1}{\mathrm{~V} 2 \times \mathrm{W}} \times 100$

Where, $\mathrm{T}=$ Titre

$\mathrm{D}=$ Dye factor

$\mathrm{V}_{1}=$ Volume made up

$\mathrm{V}_{2}=$ Aliquot of extract taken for estimation

$\mathrm{W}=$ weight of extract taken for estimation

Total soluble solid (TSS)

Total soluble solid (TSS) was estimated by using Abbe Refractrometer placing a drop of juice on its prism. Percent TSS was obtained from direct reading of this refractrometer.

\section{Total sugar}

Total sugar can be calculated by using following way: Percentage of total sugar $=$ Percentage of Reducing sugar + Percentage of Non-reducing sugar

\section{Formulation of different types of products}

The product prepared from strawberry with different formulation is coded as:

Jam: $\mathrm{C}_{1}, \mathrm{C}_{2}, \mathrm{C}_{3}$

Jelly: $\mathrm{D}_{1}, \mathrm{D}_{2}, \mathrm{D}_{3}$

Squash: $\mathrm{E}_{1}, \mathrm{E}_{2}, \mathrm{E}_{3}$

The formulation of different types of product is shown in the table:

Table 1. Formulations of strawberry jam (1000g)

\begin{tabular}{|c|c|c|c|}
\hline Ingredients & $\mathrm{C}_{1}$ & $\mathrm{C}_{2}$ & $\mathrm{C}_{3}$ \\
\hline Strawberry pulp & $450 \mathrm{~g}$ & $450 \mathrm{~g}$ & $450 \mathrm{~g}$ \\
\hline Sugar & $550 \mathrm{~g}$ & $550 \mathrm{~g}$ & $550 \mathrm{~g}$ \\
\hline Pectin & $1.5 \%$ & $1 \%$ & $0.5 \%$ \\
\hline Citric acid & $5 \mathrm{~g}$ & $5 \mathrm{~g}$ & $5 \mathrm{~g}$ \\
\hline KMS & $300 \mathrm{ppm}$ & $300 \mathrm{ppm}$ & $300 \mathrm{ppm}$ \\
\hline
\end{tabular}

Table 2. Formulations of strawberry jelly (1000g)

\begin{tabular}{|c|c|c|c|}
\hline Ingredients & $\mathrm{D}_{1}$ & $\mathrm{D}_{2}$ & $\mathrm{D}_{3}$ \\
\hline Strawberry juice & $450 \mathrm{~g}$ & $450 \mathrm{~g}$ & $450 \mathrm{~g}$ \\
\hline Sugar & $550 \mathrm{~g}$ & $550 \mathrm{~g}$ & $550 \mathrm{~g}$ \\
\hline Pectin & $1.5 \%$ & $1 \%$ & $0.5 \%$ \\
\hline Citric acid & $5 \mathrm{~g}$ & $5 \mathrm{~g}$ & $5 \mathrm{~g}$ \\
\hline KMS & $300 \mathrm{ppm}$ & $300 \mathrm{ppm}$ & $300 \mathrm{ppm}$ \\
\hline
\end{tabular}

Table 3. Formulation of strawberry squash $(1000 \mathrm{ml})$

\begin{tabular}{|c|c|c|c|}
\hline Ingredients & $\mathrm{E}_{1}$ & $\mathrm{E}_{2}$ & $\mathrm{E}_{3}$ \\
\hline Strawberry juice & $250 \mathrm{~g}$ & $250 \mathrm{~g}$ & $250 \mathrm{~g}$ \\
\hline Sugar & $371.89 \mathrm{~g}$ & $371.89 \mathrm{~g}$ & $371.89 \mathrm{~g}$ \\
\hline Citric acid & $10 \mathrm{~g}$ & $10 \mathrm{~g}$ & $10 \mathrm{~g}$ \\
\hline Water & $367.5 \mathrm{ml}$ & $367.5 \mathrm{ml}$ & $367.5 \mathrm{ml}$ \\
\hline KMS & $300 \mathrm{ppm}$ & $350 \mathrm{ppm}$ & $400 \mathrm{ppm}$ \\
\hline
\end{tabular}




\section{Processing of jam \\ Ingredients: Strawberry pulp, Sugar, Pectin, Citric acid, KMS.}

Processing procedure: First the bud free freshly mature strawberry were washed and weighted into balance. The fruit were then cut into pieces and put into blender to blend the fruit finely. Blended pulp was then filtered, strained and mixed. The pulp was homogenized and then kept into a deep container to carefully decant the extract. Total soluble solid (TSS) was measured by hand refractrometer and $\mathrm{pH}$ was measured by $\mathrm{pH}$ meter. The homogenized pulp was then placed into the cooking chamber and heated at $50-60^{\circ} \mathrm{c}$ at 5 minute and weighted amount of sugar was added to pulp. When the mixed TSS reached into $55^{\circ}$ Brix pectin was added and when TSS reached at $58^{0}$ Brix, citric acid was added to the mixture. The temperature of the mixture usually at $105-108^{\circ} \mathrm{C}$ the syrup adhering to it forms flakes on cooling it presume that the end point reach near. TSS was again measure and boiled until the TSS reached at $65^{\circ}$ Brix. Usually at 15 minutes. The mixture was kept for cooling and filled into sterilize glass jar at about $85^{\circ} \mathrm{C}$. The mixture was kept for cooling until reaches to room temperature. The mouth of glass jar was coated with wax. Glass jar was closed tightly with the cap. Then the product was stored in dry and cool place.

\section{Processing of jelly}

Ingredients: Strawberry pulp, Sugar, Pectin, Citric acid, KMS.

Processing procedure: First the bud free freshly mature strawberry were washed and weighted into balance. The fruit were then cut into pieces and put into blender to blend the fruit finely. Blended pulp was then filtered, strained and mixed. The juice was homogenized and then kept into a deep container. Total soluble solid (TSS) was measured by hand refractrometer and $\mathrm{pH}$ was measured by $\mathrm{pH}$ meter. The homogenized juice was then placed into the cooking chamber and heated at $50-60^{\circ} \mathrm{c}$ at 5 minute and weighted amount of sugar was added to pulp. When the mixed TSS reached into $55^{\circ}$ Brix pectin was added and when TSS reached at $58^{\circ}$ Brix, citric acid was added to the mixture. The temperature of the mixture usually at $105-108^{\circ} \mathrm{C}$ the syrup adhering to it forms flakes on cooling it presume that the end point reach near. TSS was again measure and boiled until the TSS reached at $65^{\circ}$ Brix. Usually at 15 minutes. The mixture was kept for cooling and filled into sterilize glass jar at about $85^{\circ} \mathrm{C}$. The mixture was kept for cooling until reaches to room temperature. The mouth of glass jar was coated with wax. Glass jar was closed tightly with the cap. Then the product was stored in dry and cool place.

\section{Processing of squash}

Ingredients: Juice, Water, Sugar, Citric acid, KMS/ sodium benzoate.

Processing procedure: After selecting the good quality fresh fruit calyx were removed and washed. The fruits were crushed with blender and then passed through muslin cloth to remove coarse particle. The juice was homogenized and then pasteurized at $70^{\circ} \mathrm{C}$ for 30 minute. Sugar and water stain were boiled and then cooled.The stained juice was then added as per formula and stirred well.The citric acid were dissolved in a little water or squash and mixed with squash. KMS/ sodium benzoate were dissolved little warm water and mixed with squash. The squash was boiled until it reaches to at least $45^{\circ}$ Brix. The squash was then filled into sterilized bottle and cooled the bottle.

\section{Sensory evaluation}

The sensory evaluation of all formulated strawberry jam, jelly, and squash was done by testing panel. The test tasting panel was made up with of 10 test panelists. The panelists were selected from the teachers, students, and employees of the department of Food Technology and Nutritional Science. They were asked to evaluate color, flavor, sweetness, sourness, stickiness, thickness, and overall acceptability by the scoring rate on a 9 point Hedonic Scale.

\section{Storage studies}

Processed strawberry jam, jelly, and squash were stored at ambient temperature $\left(27-34^{\circ} \mathrm{C}\right)$ for a period of 4 months and quality parameters were assessed. During storage the changes in TSS, acidity, $\mathrm{pH}$, color, flavor, texture, and vitamin-C and visual fungal growth were observed.

\section{Results and Discussion}

Compositional value of strawberry pulp

The extracted pulp were processed for preparing for jam, jelly, and squash and properly packed in appropriate containers/ jar. Then the sample were kept for microbiological and shelf-life studies. The composition of the fresh strawberry pulps analysis was done in the following parameters such as (Moisture, Ash, pH, Acidity, TSS, and Vitamin-C)

Table 4. Composition of fresh strawberry pulp

\begin{tabular}{|c|c|c|c|}
\hline Parameter & Strawberry pulp & Parameter & Strawberry pulp \\
\hline Moisture (\%) & 90.96 & Acidity (\%) & 1.0 \\
\hline Ash (\%) & 0.48 & TSS (\%) & 7.0 \\
\hline Reducing sugar (\%) & 4.64 & $\mathrm{pH}$ & 2.9 \\
\hline Non reducing sugar(\%) & 1.37 & Vitamin-C (mg/100g) & 57.5 \\
\hline
\end{tabular}


Table 4. showed that moisture content was found to be $90.96 \%$ which was more or less similar to findings of Sharma observed moisture content ranging $85-90 \%$, percentage of ash, reducing sugar, non-reducing sugar, and total sugar as well as TSS content were measured to be recommended level of Sharma and the values were $0.48,4.64,1.37,6.01$ and 7.0 , the result of vitamin-C content was estimated $57.5 \mathrm{mg} / 100 \mathrm{~g}$ was closely related to reported range $(30-120 \mathrm{mg} / 100 \mathrm{~g})$. The reported range of Sharma, whereas $\mathrm{pH}(2.9)$ and acidity (1.0) were found to be considerable level.

Table 5. Compositional value of strawberry products

\begin{tabular}{|c|c|c|c|c|c|c|}
\hline Product & Moisture (\%) & Ash (\%) & TSS (\%) & pH & Acidity(\%) & $\begin{array}{c}\text { Vitamin- } \\
\text { C(mg/100g) }\end{array}$ \\
\hline Jam & 30.28 & 0.28 & 66 & 2.78 & 1.0 & - \\
\hline Jelly & 30 & 0.25 & 68.5 & 2.80 & 1.0 & - \\
\hline Squash & 59.28 & 0.22 & 40.5 & 2.90 & 1.0 & 4.00 \\
\hline
\end{tabular}

The moisture content of strawberry jam, jelly and squash were $30.28 \%, 30 \%$ and $59.28 \%$ respectively. The ash content of strawberry jam, jelly and squash were $0.28 \%, 0.25 \%$ and $0.22 \%$ respectively. The TSS content of strawberry jam, jelly and squash were $66 \%, 68.5 \%$ and $40.5 \%$ respectively and the $\mathrm{pH}$ of strawberry jam, jelly and squash were 2.78 , 2.80 and 2.90.The acidity of the jam, jelly and squash were found to be $1 \%$.The amount of vitamin-C in jam and jelly was nil, but the squash contain a small amount $4 \mathrm{mg} / 100 \mathrm{~g}$.

Table 6. Storage study of strawberry jam

\begin{tabular}{|c|c|c|c|c|c|c|c|}
\hline \multirow{2}{*}{$\begin{array}{l}\text { Period of } \\
\text { storage } \\
\text { (months) }\end{array}$} & \multirow{2}{*}{$\begin{array}{c}\text { Sample } \\
\text { code }\end{array}$} & \multicolumn{3}{|c|}{ Observation } & \multirow[t]{2}{*}{ TSS (\%) } & \multirow[t]{2}{*}{$\mathrm{pH}$} & \multirow[t]{2}{*}{ Remarks } \\
\hline & & Color & Flavor & Texture & & & \\
\hline \multirow[t]{3}{*}{0} & A & Red & Satisfactory & Firm & 66 & 2.78 & Good \\
\hline & $\mathrm{B}$ & Red & Satisfactory & Firm & 66 & 2.78 & Good \\
\hline & $\mathrm{C}$ & Red & Satisfactory & Firm & 66 & 2.78 & Good \\
\hline \multirow[t]{3}{*}{1} & A & Red & Satisfactory & Firm & 66 & 2.74 & Good \\
\hline & $\mathrm{B}$ & Red & Satisfactory & Firm & 66 & 2.74 & Good \\
\hline & $\mathrm{C}$ & Red & Satisfactory & Firm & 66 & 2.74 & Good \\
\hline \multirow[t]{3}{*}{2} & $\mathrm{~A}$ & Red & Satisfactory & Firm & 66 & 2.68 & Good \\
\hline & $\mathrm{B}$ & Red & Satisfactory & Firm & 66 & 2.68 & Good \\
\hline & $\mathrm{C}$ & Red & Satisfactory & Firm & 66 & 2.68 & Good \\
\hline \multirow[t]{3}{*}{3} & $\mathrm{~A}$ & Red & Satisfactory & Firm & 66 & 2.68 & Good \\
\hline & $\mathrm{B}$ & Red & Satisfactory & Firm & 66 & 2.68 & Good \\
\hline & $\mathrm{C}$ & Red & Satisfactory & Firm & 66 & 2.68 & Good \\
\hline
\end{tabular}

The storage study of strawberry jam (A, B, and C) showed that color, flavor, texture and TSS of the product remain same during 3 months storage period. But the $\mathrm{pH}$ of the product was decreased after the first month.

Jelly: The samples of jelly (A, B, and C) were store at ambient temperature for a period of 3 months of

\section{Compositional value of strawberry product (jam,} jelly, and squash)

Vitamin-C content in strawberry was found to very low compared to other citrus fruits. It was further reduced in jams, jellies, and squash prepared from strawberry pulp because most of the vitamin-C present in the pulp was destroyed during long heating at high temperature. However, better retention of ascorbic acid in squash was observed because of mild heat treatment and using KMS as preservative. The compositions of strawberry products (jam, jelly, and squash) were analyzed for moisture content, ash, vitamin- $\mathrm{C}$, acidity, TSS, pH, and sugar. The average results are shown in table 5 .

\section{Storage study of strawberry products}

Jam: The sample of jam (A, B, and C) was stored at ambient temperature $\left(30^{\circ} \mathrm{C}\right)$ for the period of 3 month storage study and quality parameters were assessed. During storage the change in color, flavor, odor, TSS, pH, was observed. The analysis of the parameter was done according to standard analysis methods summarized by AOAC (2003) and Rangana (1994). Results were presented in Table 6. storage and quality parameters were assessed. During storage the change in color, flavor, odor, TSS, pH, was observed. The analysis of the parameter was done according to standard analysis methods summarized by AOAC (2003) and Rangana (1994). Results were presented in Table 7. 
Table 7. Storage study of strawberry jelly

\begin{tabular}{|c|c|c|c|c|c|c|c|}
\hline \multirow{2}{*}{$\begin{array}{c}\text { Period of } \\
\text { storage } \\
\text { (months) }\end{array}$} & \multirow{2}{*}{$\begin{array}{l}\text { Sample } \\
\text { code }\end{array}$} & \multicolumn{3}{|c|}{ Observation } & \multirow[t]{2}{*}{ TSS (\%) } & \multirow[t]{2}{*}{$\mathrm{pH}$} & \multirow[t]{2}{*}{ Remarks } \\
\hline & & Color & Flavor & Texture & & & \\
\hline \multirow[t]{3}{*}{0} & A & Red & Satisfactory & Firm & 68.5 & 2.80 & Good \\
\hline & $\mathrm{B}$ & Red & Satisfactory & Firm & 68.5 & 2.80 & Good \\
\hline & $\mathrm{C}$ & Red & Satisfactory & Firm & 68.5 & 2.80 & Good \\
\hline \multirow[t]{3}{*}{1} & $\mathrm{~A}$ & Red & Satisfactory & Firm & 68.5 & 2.76 & Good \\
\hline & $\mathrm{B}$ & Red & Satisfactory & Firm & 68.5 & 2.76 & Good \\
\hline & $\mathrm{C}$ & Red & Satisfactory & Firm & 68.5 & 2.76 & Good \\
\hline \multirow[t]{3}{*}{2} & $\mathrm{~A}$ & Red & Satisfactory & Firm & 68.5 & 2.70 & Good \\
\hline & $\mathrm{B}$ & Red & Satisfactory & Firm & 68.5 & 2.70 & Good \\
\hline & $\mathrm{C}$ & Red & Satisfactory & Firm & 68.5 & 2.70 & Good \\
\hline \multirow[t]{3}{*}{3} & A & Red & Satisfactory & Firm & 68.5 & 2.66 & Good \\
\hline & B & Red & Satisfactory & Firm & 68.5 & 2.66 & Good \\
\hline & $\mathrm{C}$ & Red & Satisfactory & Firm & 68.5 & 2.66 & Good \\
\hline
\end{tabular}

The storage study of strawberry jam (A, B, and C) showed that color, flavor, texture and TSS of the product remain same during 3 months storage period. But the $\mathrm{pH}$ of the product was decreased after the first month and decreases continuously.

Squash: The sample of squash (A, B, and C) was store at ambient temperature for a period of 3

Table 8. Storage study of strawberry squash

\begin{tabular}{|c|c|c|c|c|c|c|c|}
\hline \multirow{2}{*}{$\begin{array}{l}\text { Period of } \\
\text { storage } \\
\text { (months) }\end{array}$} & \multirow{2}{*}{$\begin{array}{c}\text { Sample } \\
\text { code }\end{array}$} & \multicolumn{3}{|c|}{ Observation } & \multirow[t]{2}{*}{ TSS (\%) } & \multirow[t]{2}{*}{$\mathrm{pH}$} & \multirow[t]{2}{*}{ Remarks } \\
\hline & & Color & Flavor & Texture & & & \\
\hline \multirow[t]{3}{*}{0} & $\mathrm{~A}$ & Deep orange & Satisfactory & Clear & 40.5 & 2.90 & Good \\
\hline & $\mathrm{B}$ & Deep orange & Satisfactory & Clear & 40.5 & 2.90 & Good \\
\hline & $\mathrm{C}$ & Deep orange & Satisfactory & Clear & 40.5 & 2.90 & Good \\
\hline \multirow[t]{3}{*}{1} & A & Deep orange & Satisfactory & Clear & 40.5 & 2.88 & Good \\
\hline & B & Deep orange & Satisfactory & Clear & 40.5 & 2.88 & Good \\
\hline & $\mathrm{C}$ & Deep orange & Satisfactory & Clear & 40.5 & 2.88 & Good \\
\hline \multirow[t]{3}{*}{2} & $\mathrm{~A}$ & Deep orange & Satisfactory & Clear & 40.5 & 2.83 & Good \\
\hline & $\mathrm{B}$ & Deep orange & Satisfactory & Clear & 40.5 & 2.83 & Good \\
\hline & $\mathrm{C}$ & Deep orange & Satisfactory & Clear & 40.5 & 2.83 & Good \\
\hline \multirow[t]{3}{*}{3} & $\mathrm{~A}$ & Deep orange & Satisfactory & Clear & 40.5 & 2.78 & Good \\
\hline & $\mathrm{B}$ & Deep orange & Satisfactory & Clear & 40.5 & 2.78 & Good \\
\hline & $\mathrm{C}$ & Deep orange & Satisfactory & Clear & 40.5 & 2.78 & Good \\
\hline
\end{tabular}

The storage study of strawberry jam (A, B, and C) showed that color, flavor, texture and TSS of the product remain same during 3 months storage period. But the $\mathrm{pH}$ of the product was decreased after the first month and decreases continuously.

Sensory evaluation of strawberry products (jam, jelly, and squash)

The acceptability of the strawberry product was evaluated by Hedonic rating test. The panelists were selected from the student, teacher, and employee of the Department of Food Technology and Nutritional Science, Mawlana Bhashani Science and Technology University, Tangail. The panelists were request to assigned appropriate score for general appearance and overall acceptability of the strawberry (jam, Jelly, and squash).

Strawberry Jam: Strawberry Jam were subjected to sensory evaluation, 10 judges evaluated the color, flavor, texture and overall acceptability of 3 samples. Retaining all the ingredients equal except months of storage and quality parameters were assessed. During storage the change in color, flavor, odor, TSS, pH, was observed. The analysis of the parameter was done according to standard analysis methods summarized by AOAC (2003) and Rangana (1994). Results were presented in Table 8. the using of different percentage of pectin. Three different samples were prepared. $\mathrm{C}_{1}$ was processed by $1.5 \%$ pectin. $\mathrm{C}_{2}$ was processed by $1.0 \%$ pectin. $C_{3}$ was processed by $0.5 \%$ pectin. The mean value and standard deviation of overall acceptability of different sample were presented in figure 1. By analyzing these data it was found that, sample $\mathrm{C}_{2}$ was preferable in respect of overall acceptability. It showed the highest mean value (7.8 out of 9) and the lowest standard deviation (0.442).

\section{Overall Acceptability of Strawberry Jam}

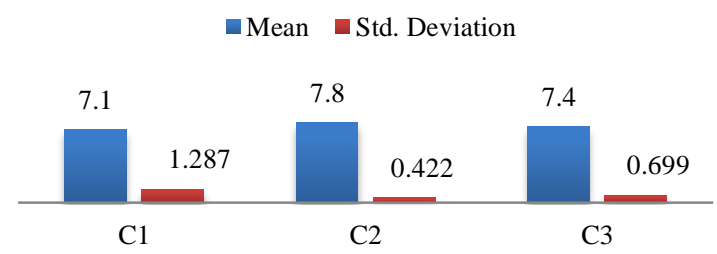

Fig. 1. The mean value and standard deviation of overall acceptability for Strawberry Jam (using Hedonic scoring scale) 
Strawberry Jelly: Strawberry Jam were subjected to sensory evaluation, 10 judges evaluated the color, flavor, texture and overall acceptability of 3 samples. Retaining all the ingredients equal except the using of different percentage of pectin. 3 different samples were prepared. $\mathrm{D}_{1}$ was processed by $1.5 \%$ pectin, $\mathrm{D}_{2}$ was processed by $1.0 \%$ pectin; $\mathrm{D}_{3}$ was processed by $0.5 \%$ pectin. The mean value and standard deviation of overall acceptability of different sample are presented in figure 2.

\section{Overall Acceptability for Strawberry Jelly}

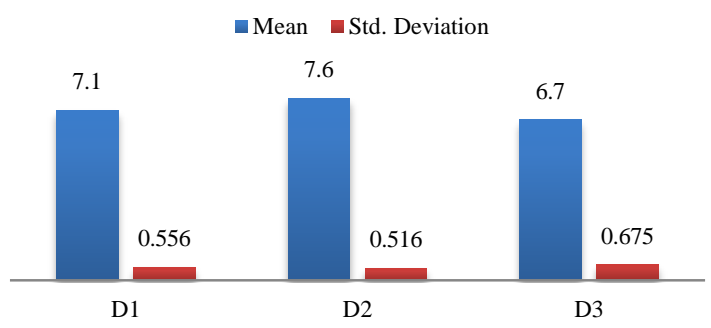

Fig. 2. The mean value and standard deviation of overall acceptability for Strawberry Jelly (using Hedonic scoring scale)

By analyzing these data it was found that, sample $\mathrm{D}_{2}$ was preferable in respect of overall acceptability. It showed the highest mean value (7.6 out of 9) and the lowest standard deviation (0.516).

\section{Conclusions}

The strawberry was collected from the local market, analyzed and jams, jelly, squash were prepared. Binding agent pectin can improve the quality of jam and jelly. By using or without using of some preservative (KMS)increase the shelf-life of jam, jelly, and squash accordingly. The moisture content of strawberry pulp was found to be $90.96 \%$, whereas the moisture content of strawberry jam, jelly and squash were $30.28 \%, 30 \%$ and $59.28 \%$ respectively. The ash content of strawberry pulp was $0.48 \%$, whereas the ash content of strawberry jam, jelly and squash were $0.28 \%, 0.25 \%$ and $0.22 \%$ respectively. The TSS of strawberry pulp was $7 \%$, whereas the strawberry jam, jelly and

\section{References}

AOAC method, 1970. Official method of Analysis, $11^{\text {th }}$ Edition, Association of Official Agricultural Chemists, Washington DC, USA.

Corbo, M.R.; Lanciotti, R.; Gardini. F.; Sinigagila, M. and Guerzoni, M.E. 2000. Effects of hexanal, trans-2-hexanal and storage temperature on shelf life of fresh sliced apples. Journal of Agriculture and Food Chemistry, 48, 2401-2408.
Strawberry squash: Strawberry Jam were subjected to sensory evaluation, 10 judges evaluated the color, flavor, texture and overall acceptability of 3 samples. Retaining all the ingredients equal except the using different concentration of KMS. 3 different samples were prepared. $E_{1}$ was processed by $300 \mathrm{ppm}$ of KMS, $\mathrm{D}_{2}$ was processed by $350 \mathrm{ppm}$ of $\mathrm{KMS} ; \mathrm{D}_{3}$ was processed by $400 \mathrm{ppm}$ of KMS. The mean value and standard deviation of overall acceptability of different sample are presented in figure 3 .

\section{Overall Acceptability of Strawberry Squash}

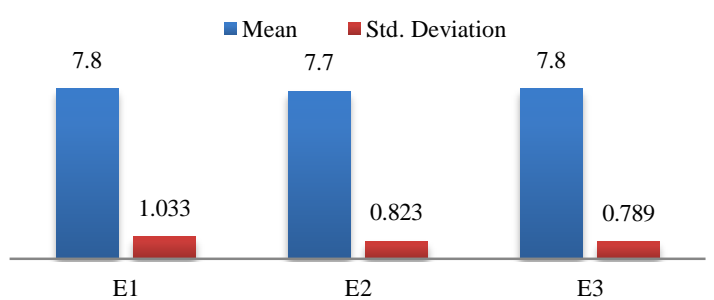

Fig. 3. The mean value and standard deviation of overall acceptability for Strawberry Squash (using Hedonic scoring scale)

By analyzing these data it was found that, sample $\mathrm{E}_{3}$ was preferable in respect of overall acceptability. It showed the highest mean value (7.8 out of 9) and the lowest standard deviation (0.789).

squash were $66 \%, 68.5 \%$ and $40.5 \%$ respectively. The $\mathrm{pH}$ of strawberry pulp was 2.90 whereas the $\mathrm{pH}$ of strawberry jam, jelly and squash were $2.78,2.80$ and 2.90.The acidity of the strawberry pulp and the processed products were remaining same. The amount of vitamin-C in strawberry pulp was $57.5 \mathrm{mg} / 100 \mathrm{~g}$ whereas the amount of vitamin-C in jam and jelly was nil, but the squash contain a small amount $4 \mathrm{mg} / 100 \mathrm{~g}$ of vitamin-C due to low heating. The products were stored in dry and cool place for 3 months. Sensory evaluation and chemical analysis of the products were done 3 months after preservation and quality attributes were found satisfactory by the test panel.

Martín, B.O.; Soliva, F.R. and Oms, O.G. 2006. Fresh-cut fruits. In: Hui Y.H. (ed.): Handbook of Fruits and Fruit Processing. Blackwell Publishing, Iowa: 129-144.

Nguyen-the, C. and Carlin, F. 1994. The microbiology of minimally processed fresh fruits and vegetables. Crit Rev Food Sci. Nutr, 34:371-401.

Rangana, S. 1994. Fruits, $3^{\text {rd }}$ edition, National Book Trust, New Delhi. 